\title{
Participation of elderly in social groups: quality of life and functional capacity
}

\author{
Participação de idosas em grupos sociais: qualidade de vida e capacidade funcional
}

Denise Akemi Simões Oliveira ${ }^{1}$, José Roberto Andrade do Nascimento Júnior², Sonia Maria Marques Gomes Bertolini $^{3}$, Daniel Vicentini de Oliveira ${ }^{1,4}$

Objective: to analyze the differences between quality of life and functional capacity in elderly participants and non-participants of groups with social activities. Methods: cross-sectional and analytical study that evaluated 31 participants of the social group (Group 1) and 31 non-participants (Group 2). The quality of life was evaluate for WHOQOL-Bref and WHOQOL-Old questionnaires and the functional capacity for Katz and Lawton scales. Results: elderly from Groups 1 and 2 showed quality of life scores in WHOQOL-Bref corresponding to 73.20 and 71.40 points. Regarding the WHOQOL-Old, both groups reached equal results (84 points). Regarding functional capacity, most elderly (77.4\%) of the Group 2 had partial or total dependence on others to accomplish instrumental activities of daily life. Conclusion: the results indicated that elderly who participate in the social group have better quality of life scores in social and intimate domains.

Descriptor: Aged; Aging; Qualida de Vida; Socialization; Nursing.

Objetivo: analisar as diferenças entre qualidade de vida e capacidade funcional em idosas participantes e não participantes de grupos com atividades sociais. Métodos: estudo transversal, analítico, que avaliou 31 participantes de grupo social (Grupo 1) e 31 não participantes (Grupo 2). A qualidade de vida foi avaliada pelo WHOQOL-Bref e WHOQOL-Old, e a capacidade funcional pelas escalas de Katz e Lawton. Resultados: as idosas do Grupo 1 e 2 apresentaram escores de qualidade de vida no WHOQOL-Bref de 73,20 e 71,40 pontos. No WHOQOL-Old ambos os grupos obtiveram os mesmos resultados (84 pontos). Em relação à capacidade funcional a maioria das idosas $(77,4 \%)$ do Grupo 2 apresentou dependência parcial ou total nas atividades instrumentais de vida diária. Conclusão: os resultados indicaram que as idosas participantes de grupo social apresentam melhores escores de qualidade de vida nos domínios social e intimidade.

Descritores: Idoso; Envelhecimento; Quality of Life; Socialização; Enfermagem.

\footnotetext{
${ }^{1}$ Faculdade Metropolitana de Maringá. Maringá, PR, Brazil.

${ }^{2}$ Univseridade Federal do Vale do São Francisco. Petrolina, PE, Brazil.

${ }^{3}$ Centro Universitário e Universidade Estadual de Maringá, PR, Brazil.

${ }^{4}$ Faculdade de Ciências Médicas, Universidade Estadual de Campinas. Campinas, SP, Brazil.

Corresponding author: Daniel Vicentini de Oliveira

Rua Boa Vista, 40, Jardim Social, CEP: 87010-030, Maringá, PR, Brazil. E-mail: d.vicentini@hotmail.com
} 


\section{Introduction}

Aging is a process of progressive and differential deterioration, and a set of morphological, physiological, biochemical and psychological changes that appear as a result of the effect of the passing of time on living beings. These translate into progressive inability of the organism to adapt to the conditions of its environment and decreasing the quality of life ${ }^{(1)}$.

The definition of quality of life, especially in old age, involves a complex panorama, presenting objective and subjective aspects. The objective factors are the absence of disease or loss of functional capacity, that is, they are focused on biological and epidemiological aspects. In turn, subjective aspects are described by the World Health Organization as the understanding that the person has of her standpoint in life, in the cultural setting and in the context of values in which we live and in relation to objectives, expectations, standards and concerns of each individual ${ }^{(2)}$.

In the elderly population, the quality of life covers a number of aspects such as the socioeconomic status, social interaction, intellectual activity, selfcare, family support, their own health, cultural, ethical, religious and functional capacity ${ }^{(3)}$.

The aging process has a negative effect on functional capacity, increasing dependency on others, and causing a reduction in the level of physical activity and an increase in the number of chronic non-communicable diseases. In order to carry out the activities of daily living, such as the instrumental activities of daily living, regular physical activity is recommended to maintain the functional capacity of the elderly and guarantee their high quality and independent life ${ }^{(4)}$.

Many strategies of action to ensure a healthy and dignified aging have been implemented in developed and developing countries. These actions often take place through programs and social groups for elderly ${ }^{(5)}$. These groups influence the aging process allowing socialization, improving self-image in society, in addition to the exchange of experiences that foster mutual growth ${ }^{(6)}$.

In order to maintain elderly in these groups, various strategies are assigned, among them craftwork, rides, games, interactive activities and physical activities that provide the exchange of experiences, ideas, as well as reflection on the daily lives of these people. However, physical exercise does not happen in most of such activities ${ }^{(7)}$.

Remain active in society, independent, with reasonable mental, physical and social health, without diseases, maintaining the desired welfare, is an important factor of the aging process. Thus, older people seek in social groups the oportunity to remain active, to get better health, quality of life and above all, to increase longevity ${ }^{(8)}$. The increase in life expectancy and quality of life of older people is related to the experience of these people in groups, which goes beyond physical and leisure activities, but also involve emotional, behavioral and social aspects among others ${ }^{(9)}$.

Thus, the aim of the present study was to analyze the differences between quality of life and functional capacity in elderly participants and nonparticipants of groups with social activities. In this sense, the following question is raised: Do elderly participating in social groups have better quality of life and functional capacity compared to elderly who do not participate in such groups?

\section{Methods}

This is a cross-sectional and analytical study in which the population was composed of 31 female elderly participants (Group 1) and 31 female elderly non-participants (Group 2) of a social group in the Uniflor municipality of the state of Paraná . Elderly aged $\geq 60$ years were included in the study. In Group 1 , the volunteers should be participating in the social group for at least three months and in Group 2, the elderly should not be practicing any form of physical exercise.

The elderly men were excluded from the study 
due to their low search for social groups. Elderly women who had neuropsychological (dementias) and incapacitating (stroke sequelae) disorders preventing them to answer the questionnaire survey were also excluded, as well as practitioners of any modality of physical exercise. Elderly of the Group 2 were evaluated in their own homes.

The sample was selected intentionally and a semistructured form was used for characterization of the elderly. This was composed of information on age, marital status, employment status, monthly income in minimum wages as reference in the Census 2015 of the Brazilian Institute of Geography and Statistic. In the item marital status, widows, separated or divorced elderly were classified as single. Also, they were questioned about the use of drugs and the presence of chronic diseases.

The evaluation of quality of life was conducted through the WHOQOL-Bref and WHOQOL-Old questionnaires. The WHOQOL-Bref consists of 26 questions, the first two relate to the individual perception of QOL and health perception and the 24 following questions are divided into four areas, namely: physical, psychological, social relationships and environment. Each domain can achieve scores from 4 to 20, and the closer to 20, the better the quality of life of individuals in the assessed area. Adding up the scores of the four areas and two questions regarding the individual's perception, minimum scores of 20 and maximum of 100 can be reached. The closer to 100 , the better the overall quality of life ${ }^{(10)}$.

The WHOQOL-Old is an additional tool to WHOQOL-Bref for evaluation in elderly populations. Thus, the assessment of quality of life was complemented by applying also the WHOQOL-Old. This consists of 24 facets, assigned to six areas: sensory abilities, autonomy, past, present and future activities, social participation, death and intimacy. Each item is composed of four questions. The transformed score was chosen and used; this is calculated from the raw score conversion (based on the sum of each question, ranging between 4 and 20) to a scale from
0 to 100 . The closer to 100 , the better the quality of life in the area rated. The total score of the WHOQOLOld was calculated by the sum of the 24 questions of the instrument and, then, the raw score varying between 24 and 120 was obtained. The conversion of the raw score into a scale of 0 to 100 represents the transformed score ${ }^{(11)}$.

One of the most cited instruments in the literature to evaluate the functional capacity is the Index of Independence in Daily Life Activity. This instrument was developed and published in 1963 by Sidney Katz and his team, it is usually called Katz Scale and assesses the functional capacity of performing basic activities of daily living ${ }^{(12)}$. This is organized to measure independence in the performance of six basic functions such as as bathing, dressing, using the toilet, moving around, feeding and the ability for excercising continence. Each item of the Katz Index may be scored from 0 to 3, representing the level of dependence and independence of the individual as follows: 0) complete independence, 1) need not human help, 2) need human assistance, 3) complete dependence ${ }^{(13)}$.

The Lawton Scale evaluates the performance of individuals in carrying out instrumental activities of daily living, and it is a general measure of the level of independence of elderly persons. This assesses adaptive or indispensable tasks for independent living in the community, such as using the telephone, shopping, preparing food, doing housework, washing laundry, using of means of transportation, preparation of medication and managing money, by allocating a score according to the subject's rated capacity to perform these activities. The scale allows to classify subjects into dependent or independent. The score that indicates greater independence is eight, and the score that greater dependence is zero ${ }^{(14)}$.

Direct interviews were used to apply all instruments, because of possible difficulty in reading, visual problems and understanding the questions. Statistical analysis was performed using the software Statistical Package for the Social Sciences version 20.0. For numeric variables, normality of data was 
checked through Kolmogorov-Smirnov test. Because the data did not show normal distribution, median and quartiles were used for characterization of results. The "U" Mann-Whitney test for independent samples was used to compare groups 1 and 2 . A chisquare test was also applied to check whether there was any association between groups 1 and 2 and sociodemographic variables. The significance adopted was $\mathrm{p}<0.05$.

The study complied with the formal requirements contained in the national and international regulatory standards for research involving human beings, .

\section{Results}

The characteristics of the profile of elderly are shown in Table 1.

Table 1 - Association between sociodemographic variables of elderly participants (Group 1) and nonparticipats (Group 2) of a social group

\begin{tabular}{|c|c|c|c|c|}
\hline \multirow[t]{2}{*}{ Variables } & $\begin{array}{c}\text { Group 1 } \\
(n=31)\end{array}$ & $\begin{array}{c}\text { Group } 2 \\
(\mathrm{n}=31)\end{array}$ & \multirow[t]{2}{*}{$\mathbf{X}^{2}$} & \multirow[t]{2}{*}{$\mathbf{p}$} \\
\hline & $f(\%)$ & $f(\%)$ & & \\
\hline \multicolumn{5}{|l|}{ Marital status } \\
\hline Married & 12 (38.7) & $8(25.8)$ & \multirow{2}{*}{1.18} & \multirow{2}{*}{0.278} \\
\hline Not married & 19 (61.3) & $23(74.2)$ & & \\
\hline \multicolumn{5}{|l|}{ Race } \\
\hline Caucasian & $20(64.5)$ & $21(67.7)$ & \multirow{2}{*}{0.07} & \multirow{2}{*}{0.786} \\
\hline Black & $11(35.5)$ & $10(32.3)$ & & \\
\hline \multicolumn{5}{|l|}{ Level of education } \\
\hline Illiterate & $3(9.7)$ & $10(32.3)$ & \multirow{4}{*}{2.29} & \multirow{4}{*}{0.127} \\
\hline Incomplete primary school & $21(67.7)$ & $15(48.4)$ & & \\
\hline Complete primary school & $5(16.1)$ & $5(16.1)$ & & \\
\hline Complete high school & $2(6.5)$ & $1(3.2)$ & & \\
\hline \multicolumn{5}{|l|}{ Occupational status } \\
\hline Active & $2(6.5)$ & $6(19.4)$ & \multirow{2}{*}{2.30} & \multirow{2}{*}{0.129} \\
\hline Inactive & $29(93.5)$ & $25(80.6)$ & & \\
\hline \multicolumn{5}{|l|}{ Monthly income (wages) ${ }^{\mathrm{a}}$} \\
\hline 1 to 2 & $31(100.0)$ & $31(100.0)$ & \multirow{2}{*}{ - } & \multirow{2}{*}{-} \\
\hline$<2$ & - & - & & \\
\hline
\end{tabular}

When analyzing the association between sociodemographic variables and elderlyr participants (Group 1) and non-participants (Group 2) of the social group, there was no significant association in any of the variables $(p>0.050)$, showing that the groups have homogeneous characteristics with respect to sociodemographic variables.

Comparing the domains of quality of life WHOQOL-Bref (Table 2), significant differences were found in the Social Relations domain $(\mathrm{p}=0.005)$, indicating that elderly from the Group $1(\mathrm{Md}=16.00)$ had higher perception of the quality of life regarding their social relations than the Group $2(\mathrm{Md}=4.67)$.

Table 2 - Comparison of domains and aspects of quality of life of elderly participants (Group 1) and non-participants (Group 2) of the social group

\begin{tabular}{|c|c|c|c|}
\hline \multirow{2}{*}{ Variables } & Group $1(n=31)$ & Group $2(n=31)$ & \multirow{2}{*}{$\mathbf{p}$} \\
\hline & Md (Q1, Q3) & Md (Q1, Q3) & \\
\hline \multicolumn{4}{|c|}{ Quality of life domains (WHOQOL Bref) } \\
\hline Domain 1 - Physical & $14.28(13.71 ; 16.57)$ & $14.28(12.57 ; 15.42)$ & 0.395 \\
\hline Domain 2 - Psychological & $15.33(14.66 ; 16.67)$ & $15.33(14.00 ; 16.00)$ & 0.148 \\
\hline $\begin{array}{l}\text { Domain } 3 \text { - Social Rela- } \\
\text { tions }\end{array}$ & $16.00(14$ & $14.67(13.33 ; 16.00)$ & $0.005^{*}$ \\
\hline Domain 4 - Environment & $14.00(13.00 ; 15.00)$ & $14.00(12.50 ; 15.00)$ & 0.360 \\
\hline Area 5 - Self evaluation & $14.00(14.00 ; 16.00)$ & $16.00(14.00 ; 16.00)$ & 0.362 \\
\hline Overall quality of life & $73.20(69.70 ; 80.40)$ & $71.40(67.10 ; 79.70)$ & 0.143 \\
\hline \multicolumn{4}{|c|}{ Facets of quality of life (WHOQOL Old) } \\
\hline $\begin{array}{l}\text { Facet } 1 \text { - Operation of the } \\
\text { senses }\end{array}$ & $14.00(13.00 ; 18.00)$ & $15.00(13.00 ; 18.00)$ & 0.910 \\
\hline Facet 2 - Autonomy & $14.00(13.00 ; 15.00)$ & $14.00(13.00 ; 14.00)$ & 0.339 \\
\hline $\begin{array}{l}\text { Facet } 3 \text { - Past, present and } \\
\text { future activities }\end{array}$ & $15.00(14.00 ; 15.00)$ & $14.00(13.00 ; 16.00)$ & 0.272 \\
\hline $\begin{array}{l}\text { Facet } 4 \text { - Social participa- } \\
\text { tion }\end{array}$ & $14.00(13.00 ; 16.00)$ & $13.00(12.00 ; 14.00)$ & $0.015^{*}$ \\
\hline Facet 5 - Death and dying & $13.00(11.00 ; 17.00)$ & $14.00(11.00 ; 16.00)$ & 0.864 \\
\hline Facet 6 - Intimacy & $15.00(13.00 ; 16.00)$ & $13.00(11.00 ; 15.00)$ & $0.025^{*}$ \\
\hline Overall quality of life & $84.00(79.00 ; 95.00)$ & $84.00(79.00 ; 87.00)$ & 0.192 \\
\hline
\end{tabular}

Significant difference was found (Table 2) in the Facets Social Participation $(p=0.015)$ and Intimacy ( $p$ $=0.025)$, showing that elderly from the Group 1 had 
higher perception of quality of life in facets related to their social participation in activities and in their intimacy, compared to elderly of the Group 2.

Table 3 shows that there was no significant association ( $p>0.05)$ between functional capacity and elderly participants (Group 1) and non-participants (Group 2) of the social group, as more than $90.0 \%$ of elderly from the Group 1 and Group 2 showed independence in daily life activities; and $51.6 \%$ of Group 1 of the elderly showed partial dependence, while $77.4 \%$ of the Group 2 had partial or total dependence to perform instrumental activities of daily life.

Table 3 - Association between functional capacity and elderly participants (Group 1) and non-participants (Group 2) of the social group

\begin{tabular}{|c|c|c|c|c|}
\hline \multirow[t]{2}{*}{ Funcional capacity } & $\begin{array}{c}\text { Group } 1 \\
(\mathrm{n}=31)\end{array}$ & $\begin{array}{c}\text { Group } 2 \\
(\mathrm{n}=31)\end{array}$ & \multirow[t]{2}{*}{$\mathbf{X}^{2}$} & \multirow[t]{2}{*}{$\mathbf{p}$} \\
\hline & $f(\%)$ & $f(\%)$ & & \\
\hline \multicolumn{5}{|l|}{ Activities of daily life } \\
\hline Independence & $30(96.8)$ & $29(93.5)$ & \multirow{2}{*}{0.35} & \multirow{2}{*}{0.547} \\
\hline Partial dependence & $1(3.2)$ & $2(6.5)$ & & \\
\hline \multicolumn{5}{|c|}{ Instrumental activities of daily life } \\
\hline Independence & $4(12.9)$ & $7(22.6)$ & & \\
\hline Partial dependence & $16(51.6)$ & $12(38.7)$ & 0.12 & 0.717 \\
\hline Total dependence & $11(35.5)$ & 12 (38.7) & & \\
\hline
\end{tabular}

\section{Discussion}

The present study identified that there was significant difference between the groups only with respect to the domains social participation and intimacy, what may be associated with reduced number of activities in the researched group, as well as with the number of weekly meetings.

That result shows that participation in groups with these characteristics can be beneficial to the aspect of social relations. These data are similar to a research carried out with elderly participants in a social group that showed greater perception of quality of life as regards their social relations, compared to the group of non-participant elderly. In this sense, socialization proved to be a very important factor in determining the quality of life of the elderly. Maintaining social relationships with friends of the same generation favors the psychological and social well-being of the elderly ${ }^{(15)}$.

The participation of elderly in these social or living groups can lead to construction of a utopia of healthy aging(7). In this sens, a redesign and implementation of new activities for the group is suggested, ie, implementation of exercise programs intended to promote improvements in health and well-being by increasing the levels in all domains of quality of life elderly participants of social groups.

The more active, the less will be the need for families and health services. So, the higher is the physical integration in the social environment, the greater the benefits for themselves and for society ${ }^{(16)}$.

As already mentioned, we also found a significant difference in facet intimacy, revealing that elderly participants in the social group showed greater perception of quality of life in that facet. It is noteworthy that the domain intimacy evaluated issues regarding companionship, ability to love and to be loved.

Elderly well integrated into the social environment and their families have a greater chance of survival and more ability to recover from illnesses. Social isolation is an important risk factor for morbidity and mortality ${ }^{(17)}$. The participation of elderly women in group activities is important because it makes their individual identity to associate with the social identity of the group, strengthening its belonging to it. Empathy established between people in groups encourages them to give their opinions on their interests in new skills that gradually give new meaning to their lives ${ }^{(18)}$.

Social or community groups promote good relationships among its members, strengthening the bonds of friendship and stimulating new connections that reach high levels of intimacy, not only among members of the group, but extending to their families $^{(18)}$.

Among the proposals of many social groups, the 
practice of physical exercises, whether sports, dance, recreational activities or even strength exercises are the most encouraged and with major results, as it brings somehow benefits to health ${ }^{(19)}$. Even with the process of aging, it is still possible gain fitness through physical exercise. In turn, this will facilitate the development of activities of daily living and instrumental daily life.

Regarding the scores on the scales for assessing the functional capacity of the elderly, both groups are functionally independet, not requiring help from another person to perform the activities of daily living and instrumental daily life. Even without regular physical exercise, these elderly women keep active through their accomplishing domestic chores, leisure and travelling. This situation was observed in a previous research where the elderly related the activity not only to the practice of physical exercise, but also to domestic activities, which may characterize a situation of non-sedentary lifestyle and functional maintenance ${ }^{(20)}$.

The population of the municipality of this research presents rural characteristics, what increases physical activity of subjects with respect to moving around, leisure and domestic activities. This could very likely justify the absence of difference between the groups in the variable functional capacity. Another research was also held in a city in the countryside of the state and this has peculiar and typical rural characteristics, such as less use of means of motorized transport, increased contact between residents and typical social habits such as meeting friends in the public square, what may be considered as a factor leading to equality in the functional ability of the two groups ${ }^{(20)}$. Therefore, the participation in the social group did not influence the improvement of activities of daily living and instrumental daily life.

Among limitations of this study is the fact that the study was done in a municipality with small number of inhabitants and more social contact among them happens if compared to the big cities. This may have influenced the similarities between groups in the evaluation of quality of life. However, despite these limitations, this study will provide health professionals such as nurses important knowledge about the need to encourage the participation of elderly in social groups and or intensify the practice of physical exercise in such groups, since this is one of the determinants of promotion of Health of elderly.

We suggest that social groups be expanded and that greater incentives for participation of elderly be carried out.

\section{Conclusion}

The study found no significant differences between participants and non-participants of a group with social activities in relation to the overall quality of life and functional capacity. However, greater functional dependence levels were found among nonparticipant elderly in the social group. The results indicated that elderly who participate in the social group have better quality of life scores in social and intimate domains.

\section{Collaborations}

Oliveira DAS and Oliveira DV contributed to the design, collection of field data, and writing of the article. Nascimento Júnior JRA contributed to analysis and interpretation of data and writing of the article. Bertolini SMMG contributed in writing, relevant review and final approval of the version to be published.

\section{References}

1. Wichimann FMA, Areosa SVC, Lepper L, Couto AN, Cardoso CMC, Moreira EP. Satisfação do idoso na convivência em grupos. Rev Contexto Saúde. 2011; 10(20):491-8.

2. Leite MT, Winck MT, Hildebrandt LM, Kirchner RM, Silva LAA. Qualidade de vida e nível cognitivo de pessoas idosas participantes de grupos de convivência. Rev Bras Ger Gerontol. 2012; 15(3):481-92. 
3. Januário RSB, Serassuelo Júnior H, Liutti MC, Decker D, Molari M. Qualidade de vida em idosos ativos e sedentários. ConSc Saúde. 2011; 10(1):112-21.

4. Oliveira DV, Bertolini SMMG, Martins Júnior J. Qualidade de vida de idosas praticantes de diferentes modalidades de exercício físico. ConSc Saúde. 2014; 13(2):187-95.

5. Benedetti TRB, Petroski EL. Idosos asilados e a prática de atividade física. Rev Bras Ativ Fís Saúde. 2012; 4(3):5-16.

6. Rodrigues LB, Cruz RVS, Moura MVA, Marinho Júnior UG, Gonzaga PD. Avaliação da qualidade de vida sexual entre idosos participantes de um grupo de convivência e lazer. Memorialidades. 2014; (21):105-32.

7. Rizzolli D, Surdi AC. Percepção dos idosos sobre grupos de terceira idade. Rev Bras Ger Gerontol. 2010; 13(2):225-33.

8. Matsudo SM, Matsudo VKR, Barros Neto TL. Efeitos benéficos da atividade física na aptidão física e saúde mental durante o processo de envelhecimento. Rev Bras Ativ Fís Saúde. 2012; 5(2):60-76.

9. Tahan J, Carvalho ACD. Reflexões de idosos participantes de grupos de promoção de saúde acerca do envelhecimento e da qualidade de vida. Saúde Soc. 2010; 19(4):878-8.

10. Silva PAB, Soares SM, Santos JFG, Silva LB. Ponto de corte para o WHOQOL-Bref como preditor de qualidade de vida de idosos. Rev Saúde Pública. 2010; 48(3):390-7.

11. Vagetti GC, Oliveira V, Barbosa Filho VC, Moreira NB, Campos W. Predição da qualidade de vida global em idosas ativas por meio dos domínios do WHOQOL-Bref e do WHOQOL-Old. Motricidade. 2012; 8(S2):709-18.
12. Lisboa CR, Chianca TCM. Perfil epidemiológico, clínico e de independência funcional de uma população idosa institucionalizada. Rev Bras Enferm. 2012; 65(3):482-7.

13. Smanioto FM, Haddad CFL. Índice de Katz aplicado a idosos institucionalizados. Rev Reve. 2011; 12(1):18-23.

14. Pereira MG, Roncon J. Relacionamento familiar em pessoas idosas: adaptação do índice de relações familiares (IFR). Rev Psic Saúde Doenç. 2010; 11(1):41-53.

15. Almeida DT, Leitão GCM, Silva LF. Qualidade de vida e percepção do envelhecimento sob a ótica do idoso. Rev Bras Prom Saúde. 2012; 13(1):2733.

16. Albuquerque AG, Oliveira GSM, Silva VL, Nascimento CB. Capacidade funcional e linguagem de idosas não-participantes e participantes de grupos de intervenção multidisciplinar na atenção primária à saúde. Rev CEFAC. 2012; 14(5):952-62.

17. Fabrício AT, Silva TBL, Kissaki PT, Vieira MG, Ordonez TN, Oliveira TB, et al. Treino cognitivo em adultos maduros e idosos: impacto de estratégias segundo faixas de escolaridade. Psico-USF. 2012; 17(1):85-95.

18. Both JE, Leite MT, Hildebrandt LM, Pilati ACL, Stamn B, Jantsch LB. Grupos de convivência: uma estratégia de inserção do idoso na sociedade. Rev Contex Saúde. 2011; 10(20):995-8.

19. Benedetti TSB, Mazo GZ, Borges LJ. Condições de saúde e nível de atividade física em idosos participantes e não participantes de grupos de convivência de Florianópolis. Ciênc Saúde Coletiva. 2012; 17(8):2087-93.

20. Ferreira OGL, Maciel SC, Costa SMG, Silva AO, Moreira MASP. Active aging and its relationship to functional independence. Texto Contexto Enferm. 2012; 21(3):513-8. 